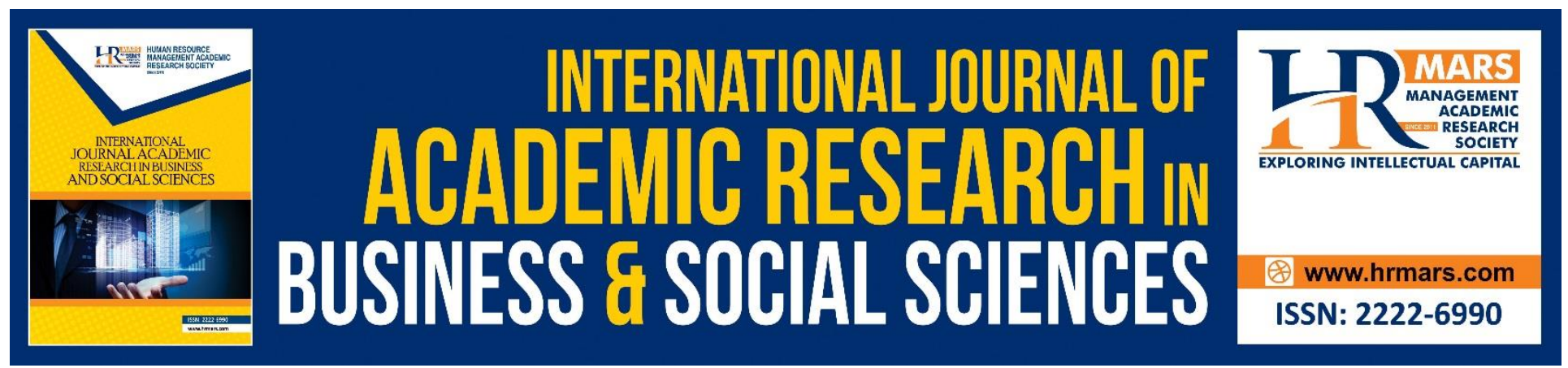

\title{
Relevance Meaning in Malay and Spanish Text
}

\section{Salina Husain, Ramiza Darmi, Syed Nurulakla Syed Abdullah, Norazmi Danuri}

To Link this Article: http://dx.doi.org/10.6007/IJARBSS/v10-i10/7908

DOI:10.6007/IJARBSS/v10-i10/7908

Received: 11 August 2020, Revised: 30 August 2020, Accepted: 21 September 2020

Published Online: 19 October 2020

In-Text Citation: (Husain, Darmi, Abdullah, \& Danuri, 2020)

To Cite this Article: Husain, S., Darmi, R., Abdullah, S. N. S., \& Danuri, N. (2020). Relevance Meaning in Malay and Spanish Text. International Journal of Academic Research in Business and Social Sciences. 10(10), 453-466.

Copyright: (c) 2020 The Author(s)

Published by Human Resource Management Academic Research Society (www.hrmars.com)

This article is published under the Creative Commons Attribution (CC BY 4.0) license. Anyone may reproduce, distribute, translate and create derivative works of this article (for both commercial and non-commercial purposes), subject to full attribution to the original publication and authors. The full terms of this license may be seen at: $\underline{\text { http://creativecommons.org/licences/by/4.0/legalcode }}$

Vol. 10, No. 10, 2020, Pg. 453 - 466

http://hrmars.com/index.php/pages/detail/IJARBSS

JOURNAL HOMEPAGE

Full Terms \& Conditions of access and use can be found at http://hrmars.com/index.php/pages/detail/publication-ethics 


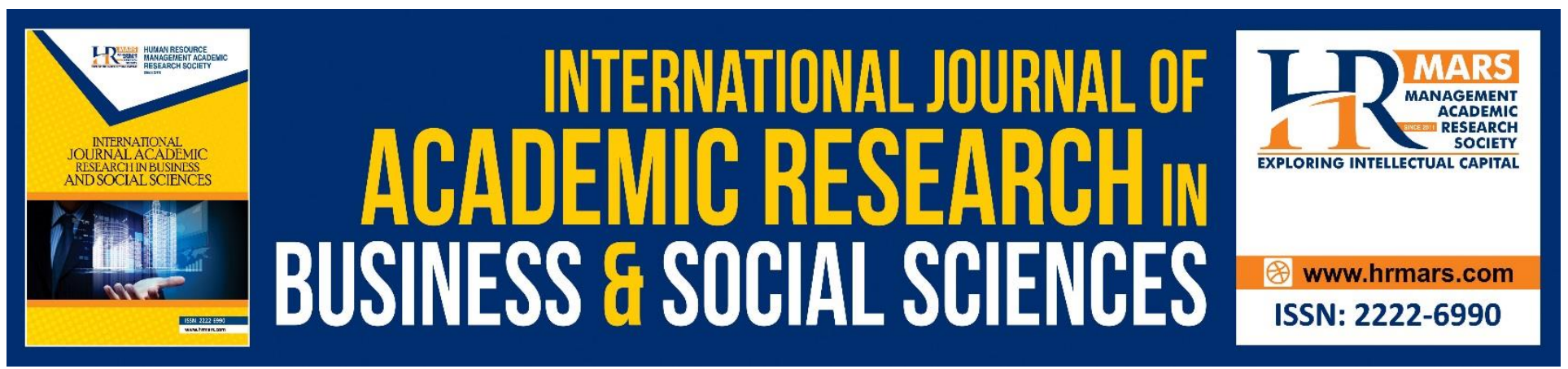

\title{
Relevance Meaning in Malay and Spanish Text
}

\author{
Salina Husain ${ }^{1}$, Ramiza Darmi², Syed Nurulakla Syed Abdullah³, \\ Norazmi Danuri ${ }^{4}$ \\ ${ }^{1,2 \& 3}$ Faculty of Modern Languages and Communication, Universiti Putra Malaysia, ${ }^{4}$ Faculty of \\ Science, Technology dan Human Development, Universiti Tun Hussein Onn \\ Email: ${ }^{1}$ linahusain@upm.edu.my, ${ }^{2}$ ramiza@upm.edu.my, ${ }^{3}$ syedakla@yahoo.com \\ ${ }^{4}$ norazmi@uthm.edu.my
}

\begin{abstract}
One of the obstacles in translating process is the grammatical structural difference between source language to target language. Therefore, this paper discussing meaning relevance in text translation in order to discover similarities and differences meaning between Malay and Spanish. The researcher has focused on four sentences from Malay to Spanish by using $A 1, A 2, A 3$ and $A 4$ label involving ten students from Universiti Putra Malaysia who taking Spanish as an elective course. The Relevance Theory (1986 and 1995) by Sperber and Wilson's is use in this paper. The objectives are to discuss translation equivalents for textual verb expressions from Malay to Spanish, and to analyse the translation equivalents based on their fuctional similarities and differences to ensure the meaning conveyed remain the same to the original text. Findings from this research can assist the teaching and learning of Spanish as a foreign language specifically in verb formation.
\end{abstract}

Keywords: Relevant Meaning, Similarity, Difference, Malay, Spanish.

\section{Introduction}

Translation is the process of changing the information of one language into another language retaining the same meaning. The translation occurs in verbal and written communication. Conflict and confusion often occur in the process of translation due to preserving semantic meaning in the target language. According to Novriyanto and Rifal (2019), translation is merely transferring the ideas from the source language to the target language, not changing the content or the purposes of the text. This is even more so when the source and target languages belong to different language families that have different grammatical structures. For example, in Malay rumah cantik but in Spanish refer as la casa bonita. The adjective in Spanish bonita (cantik) is placed after noun casa (rumah). Therefore, the relevance of any meaning in translation is very important so that the message conveyed is exact. Through this concept of translation, the researcher will investigate whether the equivalence in meaning from the source text to the target text can be preserved or differentiated. This is viewed as an important process because the purpose of translation is to give 
INTERNATIONAL JOURNAL OF ACADEMIC RESEARCH IN BUSINESS AND SOCIAL SCIENCES Vol. 10, No. 10, 2020, E-ISSN: 2222-6990 @ 2020 HRMARS

space to readers who do not understand the source language to read in the target language without affecting the intended meaning (Salina, 2011).

According to Lado in Linguistics across culture: Applied linguistics for language teacher (1957), there are several grammatical problems when we learn a foreign language. The problems occur because learners will transfer sentence form, gender and others from their first language to the target languge. The transfer process will eventually create confusion among learners when learning a foreign language. In this research, Malay is refered to as the source language while Spanish is refered to as the target Language. In Malaysia, Spanish is considered as the third or fourth foreign language learned. In his research, Fauzi (2003) viewed translation as a very complex task because it involves not only two grammatical and vocabulary systems but also elements of two cultures. Drabelnet (1958) defines translation as a process of matching that can be used when the refered context in the source language does not exist in the target language. This means that due to the complexity of translation, not everything that is translated is equivalent and appropriate to be used in the target language. Therefore, equivalent translation plays a major role in preserving the intended message. Other than equivalent meaning translation, Sperber and Wilson's Relevance Theory states that success in communication between the speaker and listener depends on optimal relevance.

According to Fauzi (2002), optimal relevance in utterances can be achieved when the listener understands the intent and the intended meaning of the speaker. Thus, it can be said that when a teacher communicates with students, the teacher needs to use examples that relate to the students' lives in order to achieve optimal relevance so that the communication is easily understood. In addition, ostensive stimulation is also stressed in the translation process as the meaning conveyed by the speaker must be parallel to the meaning understood by the listener. Furthrmore, the speaker must provide sufficient information to the listener so that relevant assumptions can be made by the listener in order to understand the context easier. Consequently, translation process will be efficient and closer to the intented, meaning that when the speaker and the listener achieve optimal relevance, sufficient ostensive stimuli and relevant assumptions are made. Evidently, it has also been found that the learners' first language also interfered with the translation. According to Galasso (2002), learners would strategically derive their first language parameter setting resulting in errors in learning the target language. Therefore, we can say that translation also can be a part of learning strategy to understand new language. This is because learning strategies play significant roles in acquisition of a language (Tian, 2019). According to Chen \& Zhang (2019), the target language readers can get the communicative intention from all the linguistic features of the target language depending on the cognitive context of the target language readers is consistent or similar to source language.

\section{Methodology}

This research uses Sperber and Wilson (1986) Relevance Theory to unravel the research problem that is to identify equivalent in sentence translation. Ten translation scripts were selected and each script has four sentences written in the Malay language as the source language and translated into Spanish as the target language. The objectives are:

- to discuss translation equivalents for textual verb expressions from Malay to Spanish 
INTERNATIONAL JOURNAL OF ACADEMIC RESEARCH IN BUSINESS AND SOCIAL SCIENCES Vol. 10, No. 10, 2020, E-ISSN: 2222-6990 @ 2020 HRMARS

- to analyse the translation equivalents based on their fuctional similarities and differences in order to preserve the intended meaning of the original text.

The researcher has labeled $A 1, A 2, A 3$ and $A 4$ to refer to the first, second, third and fourth sentences, respectively. Similarly, for analysis purpose, all the ten respondents were labeled as R1, R2, until R10.

\section{Discussion}

Ten translation scripts with four expressions in each were analysed. This study does not discuss similarities between the Malay and Spanish sentence structure but focuses on similarities and differences in the sentence structure while preserving the meaning.

Table 1: Sentence A1

\begin{tabular}{|l|l|l|}
\hline Sentence & Language & \multicolumn{1}{c|}{ Sentence structure } \\
\hline A1 & Malay & $\begin{array}{l}\text { Natalia dan Camila tiba di universiti pada pukul } 8 \\
\text { pagi. }\end{array}$ \\
\hline & English & Natalia and Camila arrived at the university at 8 a.m. \\
\hline & Spanish & $\begin{array}{l}\text { Natalia y Camila llegan a la universidad a las ocho de } \\
\text { la mañana. }\end{array}$ \\
\hline
\end{tabular}

Based on the above sentence, eight respondents successfully translated the Malay sentence to Spanish with correct grammar while retaining the meaning. The verb tiba (arrived) has been translated to Ilegan, which means 'they have arrived' referring to 'Natalia and Camila' as the subjects. With reference to Spanish grammar system, the verb is arranged corresponding to the subject- whether human or amount (Perez Saldanya, 2012). Henceforth, the verbs in Spanish go through a conjugation process, which is a process of combining the verb and the subject in order to convey intended messages. Natalia and Camila here refer to the third person plural which 'they' is. 
INTERNATIONAL JOURNAL OF ACADEMIC RESEARCH IN BUSINESS AND SOCIAL SCIENCES Vol. 10, No. 10, 2020, E-ISSN: 2222-6990 @ 2020 HRMARS

The following are examples of the tiba (arrive) llegar.

Table 2: Conjugation of Verb 'tiba' (arrived) llegar

\begin{tabular}{|c|c|c|}
\hline Subject & $\begin{array}{c}\text { 'tiba' (arrived) Verb } \\
\text { Conjugation }\end{array}$ & Meaning in Malay \\
\hline Yo (saya-I) & Llego & $\begin{array}{l}\text { Saya tiba. } \\
\text { I arrive }\end{array}$ \\
\hline Tú (awak -Your) & Llegas & $\begin{array}{l}\text { Awak tiba. } \\
\text { Your arrivae }\end{array}$ \\
\hline Él/ella (dia -he/she) & Llega & $\begin{array}{c}\text { Dia tiba. } \\
\text { He/she arrives }\end{array}$ \\
\hline Nosotros (kami - we) & Llegamos & $\begin{array}{l}\text { Kami tiba. } \\
\text { We arrive }\end{array}$ \\
\hline $\begin{array}{c}\text { Vosotros } \\
\text { (awak semua - you) }\end{array}$ & Llegáis & $\begin{array}{c}\text { Awak semua tiba. } \\
\text { You all arrive }\end{array}$ \\
\hline $\begin{array}{c}\text { Ellos/ellas } \\
\text { (mereka - they) }\end{array}$ & Llegan & $\begin{array}{c}\text { Mereka tiba. } \\
\text { They arrive }\end{array}$ \\
\hline
\end{tabular}

Therefore, the choice of the llegan conjugation form is very relevant because it represents the meaning 'They arrive' that refers to the subjects 'Natalia' and 'Camila'. It is clear that the Ilegan conjugation achieves optimal equivalent relevance because the meaning conveyed has a connection to the actions of the refered subject.

For the same exercise, two respondents committed errors in their translation that affects the original message. R5 has wrongly chosen llegais that means 'you all arrive'. The error occurs because of the confusion in choosing the subject of the pronouns. 'They' refers to the third person pronoun while 'you' refers to second person collective pronoun. On the other hand, R6 committed errors in choosing the suffix 'in' (en) which has a different and irrelevant meaning with the 'to' (a) preposition. Additionally, the expression ...en la universidad... means 'in the university', while the correct translation should mean 'to the university'. In this case, the equivalent translation has affected the meaning because the context of the sentence does not achieve optimal relevance. R6 also committed an error in translating the preposition (a) 'at' to the be verb 'is', which in Spanish is (son). As a result, 'at eight in the morning' is translated to son las ocho de la mañana (is eight in the morning), while the correct translation should be a las ocho de la mañana (at eight in the morning). Although the error committed is small, the translation has become irrelevant and does not fulfill the context of the original text because it affects the intended meaning of the speaker. According to Sperber and Wilson (1986), relevance is identified as a relationship between assumptions and context.

In a nutshell, almost all translations, with the exception of the two respondents, R5 and R6, who committed minor errors, achieved Sperber and Wilson's (1986) optimal relevance signifying successful teaching and learning process. The errors committed by the two respondents signify ostensive stimuli failure because the meaning conveyed differs from the intended meaning. 
INTERNATIONAL JOURNAL OF ACADEMIC RESEARCH IN BUSINESS AND SOCIAL SCIENCES Vol. 10, No. 10, 2020, E-ISSN: 2222-6990 @ 2020 HRMARS

Table 3: Sentence A2

\begin{tabular}{|l|l|l|}
\hline Sentence & Language & \multicolumn{1}{c|}{ Sentence structure } \\
\hline A2 & Malay & $\begin{array}{l}\text { Mereka pergi bersarapan di kafeteria terlebih } \\
\text { dahulu. }\end{array}$ \\
\hline & English & $\begin{array}{l}\text { They went to have breakfast in the cafeteria } \\
\text { first }\end{array}$ \\
\hline & Spanish & Primera ellas van a desayunar en la cafetería. \\
\hline
\end{tabular}

It has been found that almost all of the respondents have committed errors in translating sentence A2, making it difficult for the researcher to identify equivalent translations that are closest to the intended meaning. The translation errors can be seen in the following table.

Table 4: A2 Sentence Translation

\begin{tabular}{|c|c|c|c|}
\hline Respondent & Spanish & $\begin{array}{l}\text { Meaning in } \\
\text { Malay }\end{array}$ & $\begin{array}{l}\text { Meaning in } \\
\text { English }\end{array}$ \\
\hline R1 & $\begin{array}{l}\text { Ellas desayunan } \\
\text { en la cafeteria } \\
\text { primero. }\end{array}$ & $\begin{array}{l}\text { Mereka } \\
\text { bersarapan di } \\
\text { kafeteria dahulu. }\end{array}$ & $\begin{array}{l}\text { They have } \\
\text { breakfast at the } \\
\text { cafeteria first. }\end{array}$ \\
\hline $\mathrm{R} 2$ & $\begin{array}{l}\text { Ellas van a la } \\
\text { cafetería para } \\
\text { desayunan } \\
\text { primera. }\end{array}$ & $\begin{array}{l}\text { Mereka pergi ke } \\
\text { kafeteria untuk } \\
\text { mereka } \\
\text { bersarapan } \\
\text { dahulu. }\end{array}$ & $\begin{array}{l}\text { They went to the } \\
\text { cafeteria so that } \\
\text { they can have } \\
\text { breakfast first. }\end{array}$ \\
\hline R3 & $\begin{array}{l}\text { Antes de que se } \\
\text { van a la } \\
\text { desayunan en la } \\
\text { cafeteria. }\end{array}$ & $\begin{array}{l}\text { Sebelum pergi } \\
\text { untuk mereka } \\
\text { makan sarapan } \\
\text { pagi di kafeteria. }\end{array}$ & $\begin{array}{l}\text { Before they went } \\
\text { to them have } \\
\text { morning } \\
\text { breakfast at the } \\
\text { cafeteria. }\end{array}$ \\
\hline R4 & $\begin{array}{l}\text { Van a desayunar } \\
\text { en la cafetería } \\
\text { antes des. }\end{array}$ & $\begin{array}{l}\text { Mereka pergi } \\
\text { bersarapan di } \\
\text { kafeteria } \\
\text { sebelum. } \\
\text { (des: tidak } \\
\text { wujud) }\end{array}$ & $\begin{array}{l}\text { They went to } \\
\text { have breakfast at } \\
\text { the cafeteria } \\
\text { before. (des: } \\
\text { does not exist) }\end{array}$ \\
\hline R5 & Van a desayunar. & $\begin{array}{l}\text { Mereka pergi } \\
\text { bersarapan. }\end{array}$ & $\begin{array}{l}\text { They go } \\
\text { breakfast. }\end{array}$ \\
\hline R6 & $\begin{array}{l}\text { Ellos van } \\
\text { desayunan en la } \\
\text { cafetería } \\
\text { temprano. }\end{array}$ & $\begin{array}{l}\text { Mereka pergi } \\
\text { mereka } \\
\text { bersarapan awal } \\
\text { di kafeteria. }\end{array}$ & $\begin{array}{l}\text { They went they } \\
\text { have breakfast } \\
\text { early at the } \\
\text { cafeteria }\end{array}$ \\
\hline R7 & $\begin{array}{l}\text { Ellas van a } \\
\text { desayunar en la }\end{array}$ & $\begin{array}{l}\text { Mereka pergi } \\
\text { bersarapan di } \\
\text { kafeteria dahulu. }\end{array}$ & $\begin{array}{l}\text { They have } \\
\text { breakfast at the } \\
\text { cafeteria first. }\end{array}$ \\
\hline
\end{tabular}


INTERNATIONAL JOURNAL OF ACADEMIC RESEARCH IN BUSINESS AND SOCIAL SCIENCES Vol. 10, No. 10, 2020, E-ISSN: 2222-6990 @ 2020 HRMARS

\begin{tabular}{|c|c|c|c|}
\hline & $\begin{array}{l}\text { cafeteria } \\
\text { primero. }\end{array}$ & & \\
\hline R9 & $\begin{array}{l}\text { Ellas van } \\
\text { desayunar en la } \\
\text { cafetería } \\
\text { primero. }\end{array}$ & $\begin{array}{l}\text { Mereka pergi } \\
\text { bersarapan di } \\
\text { kafeteria dahulu. }\end{array}$ & $\begin{array}{l}\text { They have } \\
\text { breakfast at the } \\
\text { cafeteria first. }\end{array}$ \\
\hline R10 & $\begin{array}{l}\text { Van a el } \\
\text { cafetaría por } \\
\text { desayunan en } \\
\text { primer lugar. }\end{array}$ & $\begin{array}{l}\text { Mereka pergi ke } \\
\text { kafeteria untuk } \\
\text { mereka } \\
\text { bersarapan di } \\
\text { tempat pertama. }\end{array}$ & $\begin{array}{l}\text { They went to } \\
\text { have breakfast in } \\
\text { the first place. }\end{array}$ \\
\hline
\end{tabular}

There are several errors committed in the above translations that have affected the original meaning of the original text. The researchers believe that all the errors committed were due to the ostensive stimuli of the Relevance Theory that were not practised. Sperber and Wilson (1986) explain that ostensive stimuli are the most effective stimuli to be used by native speaker when communicating. The more the native speaker uses ostensive stimuli, the more relevant the assumptions become. The errors committed in choosing the correct translated vocabularies illustrate the mastery level in learning Spanish of the respondent is still limited. Other than that, the respondents exhibit the inclination in transferring the Malay grammar into their Spanish translation. As a result, the translations lack in grammar and accuracy in meaning.

Among the obvious errors committed are in choosing the van (they go) and desayunan (they have breakfast) verb conjugations. In Spanish, if there are two consecutive verbs in an expression, the first verb must be conjugated (having gone through the process of conjugation). That's why the words desayunar must be retained because the first verb van has already gone through the conjugation process (ir - to, van - they go). For instance, sentence A2 has two verbs- ir (go) and desayunar (have breakfast) while the subject refers to Natalia and Camila. The sentence should be written as van $a$ desayunar (they went to have breakfast) not van a desayunan (they went them have breakfast). Thus, it can be said that the relevant equivalent meaning has not fulfilled ostensive stimuli as prescribed in the Relevance Theory (1986). The errors are due to the influence Malay language was influenced during the translation process.

As for R8, there is no indication from the translation that indicates that the respondent's ostensive stimulation is very low. Although Relevance Theory (1986) stresses the semantic-pragmatic meaning, it does not guarantee that the respondents may change the sentence structure to the point it loses the original meaning or incompatible with the intended meaning. 
INTERNATIONAL JOURNAL OF ACADEMIC RESEARCH IN BUSINESS AND SOCIAL SCIENCES Vol. 10 , No. 10, 2020, E-ISSN: 2222-6990 @ 2020 HRMARS

Table 5: Sentence A3

\begin{tabular}{|l|l|l|}
\hline Sentence & Language & \multicolumn{1}{|c|}{ Sentence structure } \\
\hline A3 & Malay & Kemudian mereka pergi ke kelas ekonomi. \\
\hline & English & Then they went to economy class. \\
\hline & Spanish & Entonces/luego ellas van a la clase de economía. \\
\hline
\end{tabular}

For $A 3$, the researcher observed the relevance in meaning of the translated sentences. However, errors in choosing the correct vocabularies are still evident in every translation although the meaning conveyed can be understood. The choice of sentence relevant to the context plays an important role in translation because not every literal translation is acceptable. In translation process adjustments must be made to suit the grammar system of the target language.

Examples of translated sentences can be seen in the following table.

Table 6: Sentence A3 Translation

\begin{tabular}{|c|c|c|c|}
\hline Respondent & Spanish & $\begin{array}{c}\text { Meaning in } \\
\text { Malay }\end{array}$ & $\begin{array}{c}\text { Meaning in } \\
\text { English }\end{array}$ \\
\hline R1 & $\begin{array}{l}\text { Luego van a la } \\
\text { clase de } \\
\text { economía. }\end{array}$ & $\begin{array}{l}\text { Kemudian } \\
\text { mereka pergi ke } \\
\text { kelas ekonomi. }\end{array}$ & $\begin{array}{l}\text { Then, they went } \\
\text { to the economy } \\
\text { class. }\end{array}$ \\
\hline $\mathrm{R} 2$ & $\begin{array}{l}\text { Después, ellas } \\
\text { van a la clase de } \\
\text { la economía. }\end{array}$ & $\begin{array}{l}\text { Selepas, mereka } \\
\text { pergi ke kelas } \\
\text { ekonomi itu. }\end{array}$ & $\begin{array}{l}\text { Then, they went } \\
\text { to that } \\
\text { economy class. }\end{array}$ \\
\hline R3 & $\begin{array}{l}\text { Después de que } \\
\text { ellas van a la } \\
\text { clase de } \\
\text { economica. }\end{array}$ & $\begin{array}{l}\text { Selepas mereka, } \\
\text { mereka pergi ke } \\
\text { kelas ekonomi. }\end{array}$ & $\begin{array}{l}\text { After them, } \\
\text { they went to } \\
\text { the economy } \\
\text { class. }\end{array}$ \\
\hline R4 & $\begin{array}{l}\text { Entonces van a } \\
\text { la clase la } \\
\text { economía. }\end{array}$ & $\begin{array}{l}\text { Kemudian } \\
\text { mereka pergi ke } \\
\text { kelas ekonomi } \\
\text { itu. }\end{array}$ & $\begin{array}{l}\text { Then they went } \\
\text { to that } \\
\text { economy class. }\end{array}$ \\
\hline R5 & $\begin{array}{l}\text { Después van a } \\
\text { la clase la } \\
\text { economía }\end{array}$ & $\begin{array}{l}\text { Selepas, mereka } \\
\text { pergi ke kelas } \\
\text { ekonomi itu. }\end{array}$ & $\begin{array}{l}\text { Then, they went } \\
\text { to that } \\
\text { economy class. }\end{array}$ \\
\hline R6 & $\begin{array}{l}\text { Después de ellos } \\
\text { van economía } \\
\text { clase. }\end{array}$ & $\begin{array}{l}\text { Selepas mereka, } \\
\text { mereka pergi } \\
\text { ekonomi kelas. }\end{array}$ & $\begin{array}{l}\text { After them, } \\
\text { they went to } \\
\text { economy class. }\end{array}$ \\
\hline R7 & $\begin{array}{l}\text { Después de van } \\
\text { a la clase de } \\
\text { economica. }\end{array}$ & $\begin{array}{l}\text { Selepas daripada } \\
\text { mereka pergi ke } \\
\text { kelas ekonomi. }\end{array}$ & $\begin{array}{l}\text { After they went } \\
\text { to the economy } \\
\text { class. }\end{array}$ \\
\hline
\end{tabular}


INTERNATIONAL JOURNAL OF ACADEMIC RESEARCH IN BUSINESS AND SOCIAL SCIENCES Vol. 10, No. 10, 2020, E-ISSN: $2222-6990$ ๑ 2020 HRMARS

\begin{tabular}{|c|l|l|l|}
\hline R8 & $\begin{array}{l}\text { Ellas van a la } \\
\text { clase en } \\
\text { economia. }\end{array}$ & $\begin{array}{l}\text { Mereka pergi ke } \\
\text { kelas di ekonomi. }\end{array}$ & $\begin{array}{l}\text { They went to } \\
\text { the class at } \\
\text { economy. }\end{array}$ \\
\hline R9 & $\begin{array}{l}\text { Después de van } \\
\text { a la clase de } \\
\text { economica. }\end{array}$ & $\begin{array}{l}\text { Selepas itu, } \\
\text { mereka pergi ke } \\
\text { kelas ekonomi. }\end{array}$ & $\begin{array}{l}\text { After from, they } \\
\text { went to the } \\
\text { economy class. }\end{array}$ \\
\hline R10 & $\begin{array}{l}\text { Van a la clase } \\
\text { de el economía } \\
\text { más tarde. }\end{array}$ & $\begin{array}{l}\text { Mereka pergi ke } \\
\text { kelas ekonomi } \\
\text { sangat lewat. }\end{array}$ & $\begin{array}{l}\text { They went to } \\
\text { the economy } \\
\text { class very late. }\end{array}$ \\
\hline
\end{tabular}

In A3 translation, there are evidences that indicate equivalent meaning in translations despite minimal degree of errors committed. Nevertheless, the errors made are deemed acceptable in the learning process because they do not affect the intended meaning. For example, the choice of the article $e l$ and $l a$ in Spanish are used to determine the gender of the word. Article $e l$ is referring 'male' and la refer to femine words. The matching article for word economia is la, which means 'itu' (that) in Malay. Thus we can see that gender is not applicable in the Malay language. This situation can make students confused in cases to translate grammar structure. The choice of the word luego and entonces on the other hand is seen as fulfilling the meaning equivalent of the word (after) and both translations do not affect the overall meaning of the sentence. Meanwhile, the translation of the word economia is directly related to economy class. Thus, R1 and R4's equivalent translation is seen as fulfilling relevant semantic-pragmatic meaning.

The researcher observes English interference in R6's translation that follows English grammar form when economia clase is translated to (economic class). This translation is an error as it does not follow to the Spanish grammar rule. In this case we can say that R6 was thinking in English while translating.

Table 7: Sentence A4

\begin{tabular}{|l|l|l|}
\hline Sentence & Language & \multicolumn{1}{|c|}{ Sentence structure } \\
\hline A4 & Malay & $\begin{array}{l}\text { Dalam kelas ekonomi, mereka belajar bersama- } \\
\text { sama dengan kawan yang lain seperti Alfonso, } \\
\text { Isabel, Carlos, dan Susana. }\end{array}$ \\
\hline & English & $\begin{array}{l}\text { In the economy class, they learn with other } \\
\text { friends like Alfonso, Isabel, Carlos, and Susana }\end{array}$ \\
\hline & Spanish & $\begin{array}{l}\text { En la clase de economía, ellas estudian juntas con } \\
\text { otros amigos como Alfonso, Isabel, Carlos y } \\
\text { Susana. }\end{array}$ \\
\hline
\end{tabular}

A4 is a continuation of sentences $A 1$ to $A 3$, and the researcher observes that the clause mereka belajar (they learn) is translated correctly to estudian. Although the subject in sentence A4 is not stated, the reader can predict it from sentence $A 1$ to $A 3$ sequence. The translations for sentence A4 are in the table below. 
INTERNATIONAL JOURNAL OF ACADEMIC RESEARCH IN BUSINESS AND SOCIAL SCIENCES Vol. 10, No. 10, 2020, E-ISSN: 2222-6990 @ 2020 HRMARS

Table 8: A4 Sentence Translation

\begin{tabular}{|c|c|c|c|}
\hline Respondent & Spanish & $\begin{array}{c}\text { Meaning in } \\
\text { Malay }\end{array}$ & $\begin{array}{c}\text { Meaning in } \\
\text { English }\end{array}$ \\
\hline R1 & $\begin{array}{l}\text { En la clase de } \\
\text { economía, } \\
\text { ellos estudian } \\
\text { juntos con } \\
\text { otros amigos } \\
\text { como Alfonso, } \\
\text { Isabel, Carlos } \\
\text { y Susana. }\end{array}$ & $\begin{array}{l}\text { Dalam kelas } \\
\text { ekonomi, } \\
\text { mereka belajar } \\
\text { bersama-sama } \\
\text { dengan kawan } \\
\text { lain seperti } \\
\text { Alfonso, Isabel, } \\
\text { Carlos, dan } \\
\text { Susana. }\end{array}$ & $\begin{array}{l}\text { In the economy } \\
\text { class, they learn } \\
\text { together with } \\
\text { other friends like } \\
\text { Alfonso, Isabel, } \\
\text { Carlos, and } \\
\text { Susana. }\end{array}$ \\
\hline $\mathrm{R} 2$ & $\begin{array}{l}\text { En la clase de } \\
\text { economía, } \\
\text { ellas estudian } \\
\text { juntos con los } \\
\text { compañeros } \\
\text { como Alfonso, } \\
\text { Isabel, Carlos } \\
\text { y Susana. }\end{array}$ & $\begin{array}{l}\text { Dalam kelas } \\
\text { ekonomi, } \\
\text { mereka belajar } \\
\text { bersama-sama } \\
\text { dengan rakan- } \\
\text { rakan seperti } \\
\text { Alfonso, Isabel, } \\
\text { Carlos dan } \\
\text { Susana. }\end{array}$ & $\begin{array}{l}\text { In the economy } \\
\text { class, they learn } \\
\text { together with } \\
\text { friends like } \\
\text { Alfonso, Isabel, } \\
\text { Carlos, and } \\
\text { Susana. }\end{array}$ \\
\hline R3 & $\begin{array}{l}\text { En la clase de } \\
\text { economía, } \\
\text { estudian } \\
\text { junto con los } \\
\text { amigos como } \\
\text { Alfonso, } \\
\text { Isabel, Carlos } \\
\text { y Susana. }\end{array}$ & $\begin{array}{l}\text { Dalam kelas } \\
\text { ekonomi, } \\
\text { mereka belajar } \\
\text { bersama-sama } \\
\text { dengan kawan- } \\
\text { kawan seperti } \\
\text { Alfonso, Isabel, } \\
\text { Carlos dan } \\
\text { Susana. }\end{array}$ & $\begin{array}{l}\text { In the economy } \\
\text { class, they learn } \\
\text { together with } \\
\text { friends like } \\
\text { Alfonso, Isabel, } \\
\text { Carlos, and } \\
\text { Susana. }\end{array}$ \\
\hline R4 & $\begin{array}{l}\text { En la clase de } \\
\text { economica, } \\
\text { ellas estudian } \\
\text { con el amigas } \\
\text { de atras como } \\
\text { Alfonso, } \\
\text { Isabel, Carlos } \\
\text { y Susana. }\end{array}$ & $\begin{array}{l}\text { Dalam kelas } \\
\text { ekonomi, } \\
\text { mereka belajar } \\
\text { dengan kawan- } \\
\text { kawan di } \\
\text { belakang seperti } \\
\text { Alfonso, Isabel, } \\
\text { Carlos dan } \\
\text { Susana. }\end{array}$ & $\begin{array}{l}\text { In the economy } \\
\text { class, they learn } \\
\text { with friends at } \\
\text { the back like } \\
\text { Alfonso, Isabel, } \\
\text { Carlos, and } \\
\text { Susana. }\end{array}$ \\
\hline R5 & $\begin{array}{l}\text { En la clase la } \\
\text { economica, } \\
\text { ellos estudian } \\
\text { con sus } \\
\text { amigos como }\end{array}$ & $\begin{array}{l}\text { Dalam kelas } \\
\text { ekonomi, } \\
\text { mereka belajar } \\
\text { dengan kawan- } \\
\text { kawan mereka }\end{array}$ & $\begin{array}{l}\text { In the economy } \\
\text { class, they learn } \\
\text { with their } \\
\text { friends like } \\
\text { Alfonso, Isabel, }\end{array}$ \\
\hline
\end{tabular}


INTERNATIONAL JOURNAL OF ACADEMIC RESEARCH IN BUSINESS AND SOCIAL SCIENCES Vol. 10, No. 10, 2020, E-ISSN: 2222-6990 @ 2020 HRMARS

\begin{tabular}{|c|c|c|c|}
\hline & $\begin{array}{l}\text { Alfonso, } \\
\text { Isabel, Carlos } \\
\text { y Susana. }\end{array}$ & $\begin{array}{l}\text { seperti Alfonso, } \\
\text { Isabel, Carlos } \\
\text { dan Susana. }\end{array}$ & $\begin{array}{l}\text { Carlos, and } \\
\text { Susana. }\end{array}$ \\
\hline R6 & $\begin{array}{l}\text { En economía } \\
\text { clase, ellos } \\
\text { estudian con } \\
\text { otro amigos } \\
\text { como Alfonso, } \\
\text { Isabel, Carlos } \\
\text { y Susana. }\end{array}$ & $\begin{array}{l}\text { Dalam ekonomi } \\
\text { kelas, mereka } \\
\text { belajar dengan } \\
\text { kawan-kawan } \\
\text { seperti Alfonso, } \\
\text { Isabel, Carlos } \\
\text { dan Susana. }\end{array}$ & $\begin{array}{l}\text { In the class } \\
\text { economy, they } \\
\text { learn with } \\
\text { friends like } \\
\text { Alfonso, Isabel, } \\
\text { Carlos, and } \\
\text { Susana. }\end{array}$ \\
\hline R7 & $\begin{array}{l}\text { En la clase } \\
\text { economica, } \\
\text { estudian } \\
\text { juntos con los } \\
\text { amigos como } \\
\text { Alfonso, } \\
\text { Isabel, Carlos } \\
\text { y Susana. }\end{array}$ & $\begin{array}{l}\text { Dalam kelas } \\
\text { ekonomi, } \\
\text { mereka belajar } \\
\text { bersama-sama } \\
\text { dengan kawan- } \\
\text { kawan seperti } \\
\text { Alfonso, Isabel, } \\
\text { Carlos dan } \\
\text { Susana. }\end{array}$ & $\begin{array}{l}\text { In the economy } \\
\text { class, they learn } \\
\text { together with } \\
\text { friends like } \\
\text { Alfonso, Isabel, } \\
\text { Carlos, and } \\
\text { Susana. }\end{array}$ \\
\hline R8 & $\begin{array}{l}\text { Ellas estudian } \\
\text { con los } \\
\text { amigos como } \\
\text { Alfonso, } \\
\text { Isabel, Carlos } \\
\text { y Susana. }\end{array}$ & $\begin{array}{l}\text { Mereka belajar } \\
\text { dengan kawan- } \\
\text { kawan seperti } \\
\text { Alfonso, Isabel, } \\
\text { Carlos dan } \\
\text { Susana. }\end{array}$ & $\begin{array}{l}\text { They learn with } \\
\text { friends like } \\
\text { Alfonso, Isabel, } \\
\text { Carlos, and } \\
\text { Susana. }\end{array}$ \\
\hline R9 & $\begin{array}{l}\text { En la clase de } \\
\text { economica, } \\
\text { estudian con } \\
\text { los amigos } \\
\text { juntos como } \\
\text { Alfonso, } \\
\text { Isabel, Carlos } \\
\text { y Susana. }\end{array}$ & $\begin{array}{l}\text { Dalam kelas } \\
\text { ekonomi, } \\
\text { mereka belajar } \\
\text { dengan kawan- } \\
\text { kawan bersama- } \\
\text { sama seperti } \\
\text { Alfonso, Isabel, } \\
\text { Carlos dan } \\
\text { Susana. }\end{array}$ & $\begin{array}{l}\text { In the economy } \\
\text { class, they learn } \\
\text { together with } \\
\text { friends like } \\
\text { Alfonso, Isabel, } \\
\text { Carlos, and } \\
\text { Susana. }\end{array}$ \\
\hline R10 & $\begin{array}{l}\text { En clase de el } \\
\text { economía, } \\
\text { ellas estudian } \\
\text { con otro } \\
\text { amigos, por } \\
\text { ejemplo } \\
\text { Alfonso, } \\
\text { Isabel, Carlos } \\
\text { y Susana. }\end{array}$ & $\begin{array}{l}\text { Dalam kelas } \\
\text { ekonomi, } \\
\text { mereka belajar } \\
\text { dengan kawan- } \\
\text { kawan lain, } \\
\text { contohnya } \\
\text { Alfonso, Isabel, } \\
\text { Carlos y Susana. }\end{array}$ & $\begin{array}{l}\text { In the economy } \\
\text { class, they learn } \\
\text { together with } \\
\text { other friends, for } \\
\text { example } \\
\text { Alfonso, Isabel, } \\
\text { Carlos, y Susana. }\end{array}$ \\
\hline
\end{tabular}


Most respondents were able to translate sentence A4 although there were several errors they made, such as choosing the wrong equivalent translation and function of the word (economy) which is translated to economía and economica. The word economía functions as the noun for the word 'economy', whereas economica functions as an adjective for the word 'economy'. Therefore, the more appropriate equivalent translation that is closest to the original message for (economy class) should be economía. But we can still understand the meaning because of the words choices is quite similar to the original text. From the translations, it can be observed that only respondents R1, R2 and R3 provided translations that are equivalent to the intended meaning of the original text. Here we can see how the relevance meaning was functioning to find the similirities.

In addition, the term 'friends' is translated in two forms that are amigos and los compañeros. The semantic-pragmatic meaning equivalent in this instance does not interfere with the meaning of the intended message because amigos mean 'friends' while los compañeros means 'companions'. They are both different in vocabulary items but 'friend' and 'companions' both generally mean the same that is 'close acquaitance'. The different meanings of both words do not affect the meaning of the sentence.

Based on the above discussions, the researcher can summarise that translation relevance can be divided to two very important criteria as emphasised in the Relevance Theory (1986);

\section{(a) Relevance Context Selection}

Based on the translations discussed earlier, it is evident that the selection of the correct context will immensely preserve the intended meaning of the original text. Context selection is very important to ensure that the translation process still retains the intended meaning so that readers can understand the message conveyed in the source language. Hence, if the context of the source and target languages do not match, the intended meaning will be misunderstood resulting in poor translation. For example:

Natalia y Camila Ilegáis a la universidad...

(Natalia dan Camila awak semua tiba ke universiti...)

(Natalia and Camila all of them arrived at the university...)

Clearly the matching context selected, which is llegáis has disrupted the overall meaning of the translated sentence because the correct conjugation that fulfills the intended meaning of the original text is Ilegan (they arrive) that refers to the subject Natalia and Camila which is third pronouns plural.

(b) Relevance Connection of Semantic-Pragmatic

It goes without saying from the translations produced by respondents that both Malay language and Spanish have different grammar structures. In Spanish, stress is given on the verb conjugation form within a constructed sentence. Although the grammar structures of both languages are different, the most important aspect in translation is the preservation of the intended meaning of the source language. 
INTERNATIONAL JOURNAL OF ACADEMIC RESEARCH IN BUSINESS AND SOCIAL SCIENCES Vol. 10, No. 10, 2020, E-ISSN: 2222-6990 @ 2020 HRMARS

Example sentences are as follow:

(i) En la clase de economía, ellos estudian juntos con otros amigos como Alfonso, Isabel, Carlos y Susana.

(Dalam kelas ekonomi, mereka belajar bersama-sama dengan kawan lain seperti Alfonso, Isabel, Carlos, dan Susana.) In economy class, they learn together with other friends like Alfonso, Isabel, Carlos, dan Susana.

(ii) En la clase de economía, ellas estudian juntos con los compañeros como Alfonso, Isabel, Carlos y Susana.

(Dalam kelas ekonomi, mereka belajar bersama-sama dengan rakan-rakan seperti Alfonso, Isabel, Carlos, dan Susana.)

In economy class, they learn together with other companions like Alfonso, Isabel, Carlos, dan Susana.

In sentence (i) the subject reference used is otros amigo which means 'other friend'. Respectively, in sentence (ii), los compañeros may mean companions. Hence, both sentences mean the same because they have the same matching semantic-pragmatic context. According to Cambridge dictionary oline, 'companion' refers to person you spend a lot of time because you are friends. So we can accept it because of the semantic-pragmatic connection where the meaning can be understood.

\section{Conclusion}

The researcher can conclude that there is evidence of translations that have fulfilled the meaning relevance of the original text. This supports the use of the Relevance Theory as a guide in translating foreign languages as the theory emphasises on the preservation of the intended message eventhough both languages have different grammar structure. It has also been proven that translation process becomes more complicated if the translator has mastery over both the source and target languages. As a result, errors are committed due to interference of first language. The researcher has proven in the discussion that respondents have achieved to match meaning relevance in translating athough minor errors were made. The errors were considered as evidence that learners were experimenting their hypothesis about Spanish grammar. Unfortunately, the learners' first language seemed to have interfered with their translation. These translations proven that the process of teaching and learning Spanish took place.

The translation process can train students to practise the knowledge they have gained. This is because translation can develop abilities, flexibility, and focus on accuracy and clarity in finding the appropriate word match. Students are free to use their choices of words or sentences as long as the meanings are retained. In this study students who learned Spanish were able to translate the Spanish text into the Malay language since they have acquired the skills besides the knowledge in both languages. 
INTERNATIONAL JOURNAL OF ACADEMIC RESEARCH IN BUSINESS AND SOCIAL SCIENCES

Vol. 10, No. 10, 2020, E-ISSN: 2222-6990 @ 2020 HRMARS

\section{References}

Cambridge Dictionary. (2020). Retrieved from https://dictionary.cambridge.org/dictionary/english/analyse?q=analysing.

Chen, Y., \& Zhang, Y. (2019). Cognitive-Pragmatic Strategies for English Translation of Colloquial Metaphors in Political Discourse. International Journal of Applied Linguistics and Translation. Vol. 6, No. 3, pp. 89-95

Fauzi, M. J. (2002). Penterjemahan Pragmatik dalam Konsep Masa Arab-Melayu: Satu Analisis Teori Relevan. Jurnal Pertanika Sains Sosial dan Kemanusiaan, bil. 10(2): 153-164. (Malay paper)

Fauzi, M. J. (2003). Penterjemahan Bahasa Figuratif Arab-Melayu: Satu Analisis Teori Relevans. Tesis PhD. UKM, Malaysia. (Malay paper)

Joseph, G. (2002). Interference in Second Language Acquisition: A Review of the Fundamental Difference Hypothesis. Transfering the 'Pro-drop' Parameter from Spanish to English. Retrieved from http://www.csun.edu/ galasso/pro.pdf

Lado, R. (1957). Linguistics Across Culture. Applied Linguistics for Language Teachers. Ann Arbor: University of Michigan Press

Novriyanto, N., \& Rifal, H. (2019). Translation Problems Analysis of Students' Academic Essay. International Journal of Linguistics, Literature and Translation (IJLLT), 2(5), 1-11

Saldanya, P. M. (2012). Morphological Structure of Verbal Forms. The Handbook of Hispanic Linguistics. United Kingdom: Wiley-Blackwell.

Salina, H. (2011). Pendekatan Analisis Kontrastif dalam Terjemahan Teks Bahasa Sepanyol dan Bahasa Melayu. Jurnal Bahasa. 129-145. (Malay paper)

Sperber, D., \& Wilson, D. (1986). Relevance Communication and Cognition. United Kingdom: Basil Blackwell.

Tian, T. (2019). A Comparative Study on Vocabulary Learning Strategies by Chinese English Majors and Non-English Majors. International Journal of Applied Linguistics and Translation. Vol. 5(4), 89-94. 